\title{
Possible implication of lysophosphatidylcholine in cell fusion accompanying implantation in rabbits
}

\author{
C. Morin, J. Langlais* and R. D. Lambert $\dagger$ \\ Ontogénie et Reproduction, CHUL Research Center, 2705 Laurier Blvd (Room S-762), Ste-Foy, \\ Québec, Canada G1V $4 G 2$
}

\begin{abstract}
Summary. Implantation in rabbits involves the cellular fusion of trophoblastic and uterine epithelial cells resulting in embryo penetration of the uterine endometrium. Since lysophospholipids, known to have fusigenic properties, could be responsible for this cell fusion, the metabolism of lysophospholipids was studied throughout gestation in blastocyst/yolk sac and extracoelic amnioallantoic fluids. Analysis of phospholipid composition revealed that lysophospholipids are present in blastocyst/yolk sac fluid. Their concentrations and haemolytic activity change during pregnancy. They increase and reach their highest values during days 7 to 9 , the implantation days in rabbits. A clear correlation was observed between lysophosphatidylcholine concentrations in blastocyst/yolk sac fluid and haemolysis induced by this fluid. Phosphatidylcholine concentrations, phospholipase $\mathbf{A}_{2}$ activity, which generates lysophospholipids, and lysophospholipase A activity which hydrolyses lysophosphatidylcholine into fatty acid, were at their highest value at day 12 . These data suggest that a transient accumulation of lysophospholipids could ensure local cell fusion. Moreover, we propose that the lysophospholipid concentrations in blastocyst/yolk sac fluid are dependent upon activities of phospholipase $A_{2}$ and lysophospholipase.
\end{abstract}

Keywords: cell fusion; syncytiotrophoblast; implantation; phospholipase $\mathrm{A}_{2}$; lysophospholipids; rabbit

\section{Introduction}

Implantation of the embryo in the uterine endometrium involves several morphological and biochemical changes in the embryo and the uterine cells. In addition to the synchrony between the egg development and uterine receptivity (Psychoyos, 1986), which is largely directed by ovarian hormones (Finn, 1967; Shelesnyak \& Marcus, 1970), successful implantation implies increasing vascularization (Kennedy, 1986, 1987; Moulton \& Koenig, 1986), stimulation of uterine growth (Shelesnyak, 1986) and induction of the decidual reaction (Kennedy, 1985; Shelesynak, 1986). Several factors, such as histamine, prostaglandins, oestradiol and platelet-activating factor (PAF) have been suggested to be involved in the initiation of these phenomena (Kennedy, 1985; Dey \& Johnson, 1986; Shelesnyak, 1986; Acker et al., 1988, 1989; Harper, 1989).

It is also well known that cell fusion in the embryo or between the embryo and the endometrial cells occurs during implantation (Schlafke \& Enders, 1975). For instance, the formation of syncytial trophoblast results from cell fusion (Enders \& Schlafke, 1971). This has been observed in several animal species, such as guinea-pigs, man and rabbits (Schlafke \& Enders, 1975; Edwards, 1980). Embryonic invasion of the endometrium in rabbits involves fusion of the trophoblastic

\footnotetext{
*Present address: Maisonneuve-Rosemont Hospital, 5415 Boul. de l'Assomption, Montréal, Québec,

Canada HIT 2M4.
}

$\dagger$ Reprint requests. 
cells with the endometrial cells (Böving, 1962). However, the mechanisms leading to such tissue transformation are not known.

Lysophospholipids are known to have fusigenic properties (Shohet \& Haley, 1972; Ahkong et al., 1973; Weltzien, 1979) and could, therefore, be good candidates to explain the cell fusion observed at the time of syncytiotrophoblast formation and implantation. Since the thin glycocalyx of the microvilli of the uterine epithelium is often interrupted when in close contact with the trophoblast (Enders \& Schlafke, 1971), we can hypothesize that if lysophosphatidylcholine (LPC) is involved in the process of cell fusion, it may come from the embryo or be produced locally by the endometrium. This could ensure local fusion at the implantation site instead of overall fusion in the uterus.

The possible implication of LPC in the fusion of uterine epithelial cells at the implantation site was established by measuring LPC concentrations and haemolytic properties of blastocoelic/yolk sac fluid and extracoelic-amnioallantoic fluid in rabbits. This animal is a particularly interesting experimental model because it is characterized by three combinations of cell fusion at the trophoblastic or the epithelial levels during implantation (Böving, 1962; Schlafke \& Enders, 1975; Enders \& Schlafke, 1979). The enzymes phospholipase $\mathrm{A}_{2}\left(\mathrm{PLA}_{2}\right)$ and lysophospholipase $\mathrm{A}$ (LPLA) controlling the concentrations of LPC were also assayed, to characterize the variation in LPC concentration during gestation.

\section{Materials and Methods}

\section{Animals}

Mature New Zealand White rabbits weighing 3-3.5 kg were used. Rabbits in oestrus were identified by oedema and purple hue of the vulvae. In our experiments, day 0 corresponds to the day of onset of oestrus. On that day, females were injected i.v. with 75 iu of human chorionic gonadotrophin (hCG, A.P.L.; Ayerst Laboratories, Montreal, Canada), and were mated.

\section{Treatment of animals}

Peripheral blood was collected by cardiac puncture on days $0,6 \cdot 5,7,8,9,10,12,15$ and 25 of gestation. Serum was obtained after centrifugation $\left(1650 \mathrm{~g}, 4^{\circ} \mathrm{C}, 10 \mathrm{~min}\right)$ of coagulated blood.

\section{Embryo-fetal fluid}

After blood collection, the females were killed and the uterine horns were excised. The embryo-fetus (days 6.5 to 12) was punctured through the uterine wall to yield blastocyst/yolk sac fluid. At days 15 and 25 , the uterus was dissected to disclose the fetus and the intact annexe, thus avoiding blood contamination of the extracoelicamnioallantoic fluid. All embryo or fetal fluids were aspirated using a 5-ml sterile syringe. The fluids were then centrifuged for $10 \mathrm{~min}$ at $1650 \mathrm{~g}\left(4^{\circ} \mathrm{C}\right)$ and the supernatants were collected. All the biological samples were kept frozen at $-20^{\circ} \mathrm{C}$ and were regrouped under the same generic denomination as embryo-fetal fluid (EFF).

\section{Reaction mixture for measurement of activity of PLA ${ }_{2}$ and LPLA}

The L-3 phosphatidylcholine, 1-palmitoyl-2 $\left[\mathrm{I}^{14} \mathrm{C}\right]$ linoleoyl $\left(59 \mathrm{mCi} \mathrm{mmol}{ }^{-1}\right.$; Amersham, Canada) or L-lyso-3phosphatidylcholine, $\left[1{ }^{14} \mathrm{C}\right]$ palmitoyl $\left(59 \mathrm{mCi} \mathrm{mmol}^{-1}\right.$; Amersham, Canada) contained in toluene/ethanol $(1 / 1: \mathrm{v} / \mathrm{v})$ was evaporated, solubilized by sonification (Vibracell: Sonics, USA: $20 \mathrm{~W}, 50 \%$ duty cycle, output $6,30 \mathrm{~s}$ ) in Tris-buffered saline containing $50 \mathrm{mmol}$ Tris $1^{-1}, 0.56 \% \mathrm{NaCl}$ and $6 \mathrm{mmol} \mathrm{CaCl}_{2} 1^{-1}$ and used as substrate for measurement of enzyme activity. This was done by adding $100 \mu \mathrm{l}$ of substrate $\left(1.0 \times 10^{5}\right.$ c.p.m. in $\left.100 \mu \mathrm{l}\right), 100 \mu \mathrm{l}$ of sample and $400 \mu \mathrm{l}$ of Tris-buffered saline in $16 \times 100 \mathrm{~mm}$ glass test tubes. This reaction mixture was incubated for $4 \mathrm{~h}$ at $37^{\circ} \mathrm{C}$ before extraction in chloroform/methanol (2/1: v/v; BDH Chemicals): $3 \mathrm{ml}$ of chloroform/methanol $(2 / 1: \mathrm{v} / \mathrm{v})$, $100 \mu \mathrm{KCl}\left(0.5 \mathrm{mmol}^{-1}\right)$ and $300 \mu \mathrm{H}_{2} \mathrm{O}$ were added to each tube, which was vortexed and centrifuged ( $5 \mathrm{~min}$, $1650 \mathrm{~g}$ ). Two phases were observed: the organic phase at the bottom was carefully recovered and transferred in a $13 \times 100 \mathrm{~mm}$ tube using a Pasteur pipette. The remaining hydrophilic phase was left in the tube for a second extraction which was done to improve recovery of phospholipid and fatty acid. The chloroform/methanol extract was evaporated under a nitrogen gas stream. 


\section{Thin-layer chromatography}

Two kinds of thin-layer chromatography (TLC) plates were used: TLC aluminium sheets of silica gel $(0.2 \mathrm{~mm}$ thick) from Merck, or Linear-K silica gel $(0.25 \mathrm{~mm}$ thick) from Whatman, USA. They were washed in a solvent solution (petroleum spirit/diethyl ether/acetic acid: 80/20/1; BDH Chemicals).

The phospholipid and fatty acid residues obtained after chloroform/methanol extraction were resuspended in $100 \mu \mathrm{l}$ of chloroform/methanol (2/l: $\mathrm{v} / \mathrm{v})$ and deposited onto the washed TLC plates. Lipids from human serum, oleic acid and diacylglycerol were used as standards. The chromatographic chambers were filled $(200 \mathrm{ml})$ with a solvent system consisting of petroleum spirit/diethyl ether/acetic acid (80/20/1). After the solvent migrated completely, the plates were dried and stained with iodine vapour to locate the fatty acids (Fig. 1a). Autoradiography $\left(12 \mathrm{~h},-80^{\circ} \mathrm{C}\right)$ using Kodak X-Ray film (XAR 5, 35 $\times 43 \mathrm{~cm}$ ) was also done to locate the radioactivity on TLC (Fig. lb). The radioactive spots were then scraped from the plates, and radioactivity in the powder containing fatty acids, phospholipids or cholesterol esters was measured using the scintillation cocktail formula 963 (NEN) and a Beckman liquid scintillation system (LS-3801).

(a)

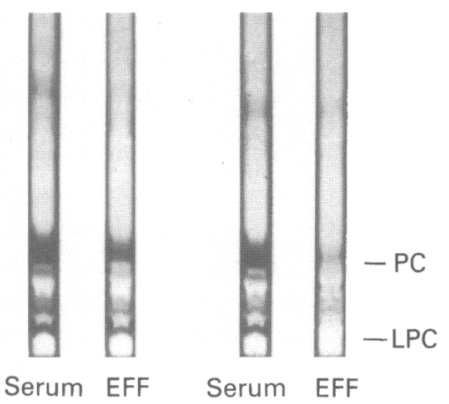

(b)

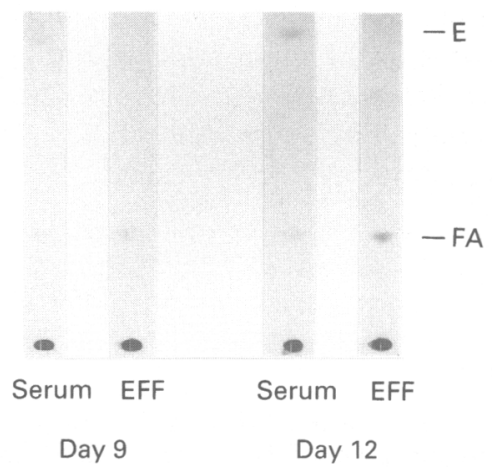

Fig. 1. Thin-layer chromatography pattern of phosphatidylcholine (PC) and lysophosphatidylcholine (LPC) concentrations in serum and embryo-fetal fluid (EFF) (a) collected at days 9 and 12 of pregnancy in rabbits and (b) corresponding autoradiography after incubation of the samples for $4 \mathrm{~h}$ with L-3-phosphatidylcholine, 1-palmitoyl-2 $\left[1-{ }^{14} \mathrm{C}\right]$ linoleoyl. E: labelled cholesterol ester produced during incubation; FA: labelled fatty acid produced during incubation.

\section{Calculation of activity of PLA ${ }_{2}$ and LPLA}

Activity of PLA $\mathrm{A}_{2}$ was expressed as the percentage of total $\left[{ }^{14} \mathrm{C}\right]$ phosphatidylcholine deacylated during the assay. The percentage of deacylation was calculated by dividing c.p.m. migrating with fatty acids by total counts scraped from TLC, including $\left[{ }^{14} \mathrm{C}\right]$ phosphatidylcholine.

The LPLA activity was also determined by the transformation of L-lyso-3-phosphatidylcholine, $1-\left[1-{ }^{14} \mathrm{C}\right]$ palmitoyl in $\left[1-{ }^{14} \mathrm{C}\right]$ palmitic acid and glycerylphosphorylcholine. The calculation was done as for PLA $\mathrm{A}_{2}$ activity.

\section{Evaluation of concentrations of phosphatidylcholine and lysophosphatidylcholine}

A modified extraction procedure was used: the biological samples ( $100 \mu \mathrm{l}$ of EFF or sera) were extracted using $100 \mu \mathrm{l}$ of $\mathrm{KCl}\left(0.5 \mathrm{~mol} \mathrm{l}^{-1}\right), 900 \mu \mathrm{l}$ of water and $3 \mathrm{ml}$ of chloroform/methanol. After extraction, each sample was dissolved in $100 \mu \mathrm{l}$ of chloroform/methanol (2/1: v/v) (BDH Chemicals) spotted on a TLC silica gel (Whatman no. $704866-82,20 \times 20 \mathrm{~cm}, 250 \mu \mathrm{m}$ thick, LK60) and migrated in chloroform/methanol/water $(65 / 25 / 4)$ for $3 \mathrm{~h}$. After spraying with phosphomolybdic acid (Fisher, New Jersey, USA; 10\%:w/v) dissolved in $99 \%$ ethanol, the plates were heated for $10 \mathrm{~min}$ at $200^{\circ} \mathrm{C}$. Concentrations of phosphatidylcholine and LPC were evaluated using an Image Analysing system (RAS system, Amersham, Canada) and values were quantified according to standardization using known concentrations of commercial preparations.

\section{Preparation of erythrocytes}

A 5-ml sample of human blood was gently mixed with EDTA. After centrifuging for $10 \mathrm{~min}$ at $940 \mathrm{~g}\left(20^{\circ} \mathrm{C}\right)$, the plasma and the buffy layer, containing leucocytes, were discarded; $1 \mathrm{ml}$ of erythrocytes was added to $4 \mathrm{ml}$ of 


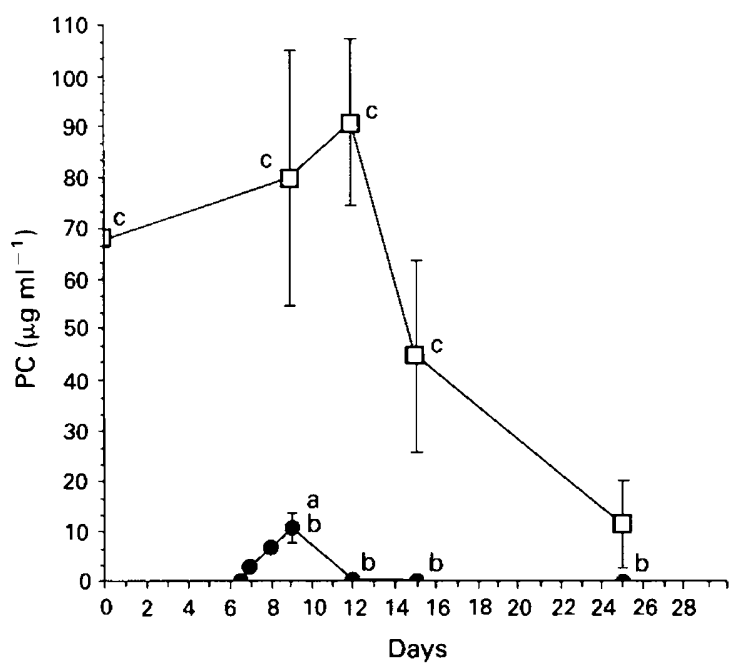

Fig. 2. Phosphatidylcholine (PC) concentrations in serum $(\square)$ and embryo-fetal fluid (EFF) (O) during gestation in rabbits. Each point represents the mean \pm SEM of four (days 15 and 25), fourteen (days 9 and 12) and one (days 6.5, 7 and 8) samples. a, Significantly different from the following EFF value $(P<0.05)$; b, significantly different from the autologous serum value $(P<0.01)$; and c, significantly different $(P<0.01)$ from day 25 serum. Statistical tests were done on log-transformed data to ensure normality and homogeneous variance.

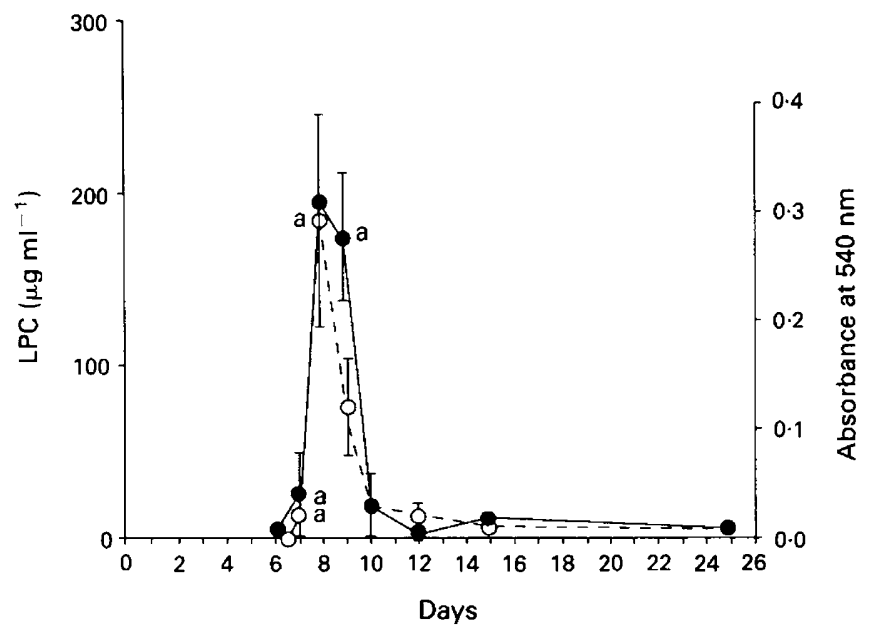

Fig. 3. Lysophosphatidylcholine (LPC) concentrations $(O)$ and haemolytic properties $(O)$ of embryo-fetal fluid (EFF) during gestation in rabbits. Four samples were tested, except at day 8 where $n=3$. a, Significantly different from the following value $(P<0.01) ; r=0.717$ $(P<0.001)$.

phosphate buffer $\left(0.01 \mathrm{~mol} \mathrm{l}^{-1}\right), 0.8 \% \mathrm{CaCl}_{2}$ at $\mathrm{pH} 7.4$ and $280 \mathrm{mOs}$. From this $1 / 5$ dilution, $3.49 \mathrm{ml}$ was recovered and mixed with $96.5 \mathrm{ml}$ of phosphate buffer and then incubated for $24 \mathrm{~h}$ at $37^{\circ} \mathrm{C}$ and $5 \% \mathrm{CO}_{2}$ to induce ATP depletion of erythrocytes. The concentration of erythrocytes from the solution was determined using a haematocytometer.

\section{Measurements of haemolysis}

A standard curve of haemolysis was performed and the concentration of erythrocytes corresponding to 0.5 of optical density at $540 \mathrm{~nm}$ was used for the experiments. This quantity of erythocytes was added to $200 \mu \mathrm{l}$ of EFF or 
Table 1. Lysophosphatidylcholine concentrations and haemolytic properties of embryo-fetal fluid and autologous sera collected at days 9 and 12 of gestation in rabbits

\begin{tabular}{lcr}
\hline & $\begin{array}{c}\text { Lysophosphatidylcholine } \\
\left(\mu \mathrm{g} \mathrm{ml}^{-1}\right)\end{array}$ & $\begin{array}{c}\text { Absorbance } \\
(540 \mathrm{~nm})\end{array}$ \\
\hline $\begin{array}{l}\text { Day 9 } \\
\text { Serum }\end{array}$ & $108 \pm 16 \quad(3)$ & $0.39 \pm 0.03(3)$ \\
Embryo-fetal fluid & $71 \pm 21 \quad(3)$ & $0.32 \pm 0.06(3)$ \\
Day12 & & \\
$\quad$ Serum & $117 \pm 12 \quad(3)$ & $0.39 \pm 0.03(3)$ \\
Embryo-fetal fluid & $17 \pm 9^{* \dagger(3)}$ & $0 \pm 0^{* \dagger}(3)$ \\
\hline
\end{tabular}

Number of samples in parentheses.

*Value on day 12 significantly different from that on day $9(P<0.05)$.

$\dagger$ Value for embryo-fetal fluid significantly different from that for serum $(P<0.0 \mathrm{I})$.

Table 2. Haemolytic activity of sera upon addition of phospholipase $\mathrm{A}_{2}$ $\left(\mathrm{PLA}_{2}\right)$ at day 9 in rabbits

\begin{tabular}{ll}
\hline & Absorbance $(540 \mathrm{~nm})$ \\
\hline Serum & $0.083 \pm 0.001^{* *}(2)$ \\
Serum + PLA 2 & $0.172 \pm 0.014 \quad(2)$ \\
PLA $_{2}$ & $0.009 \pm 0.002 \quad(2)$ \\
\hline
\end{tabular}

Bee venom PLA 2 from Sigma (St Louis, MO) was added at $40 \mu \mathrm{g} \mathrm{ml}^{-1}$ and incubated at $37^{\circ} \mathrm{C}$ for $3 \mathrm{~h}$.

Number of samples in parentheses.

**Significantly different $(P<0.01)$ from the two other groups.

Table 3. Concentration of phosphatidylcholine in embryo-fetal fluid during gestation in rabbits

\begin{tabular}{lcr}
\hline Day of gestation & \multicolumn{2}{c}{$\begin{array}{c}\text { Phosphatidylcholine } \\
\left(\mu \mathrm{g} \mathrm{ml}^{-1}\right)\end{array}$} \\
\hline $6 \cdot 5$ & 0 & $(2)$ \\
7 & 3 & $(1)$ \\
8 & 6 & $(1)$ \\
9 & $11 \cdot 1 \pm 2 \cdot 7$ & $(14)$ \\
12 & $0.4 \pm 0 \cdot 3^{*}(15)$ \\
15 & 0 & $(4)$ \\
25 & 0 & $(4)$ \\
\hline
\end{tabular}

Number of samples in parentheses.

*Significantly different from day-9 value $(P<0.05)$. 


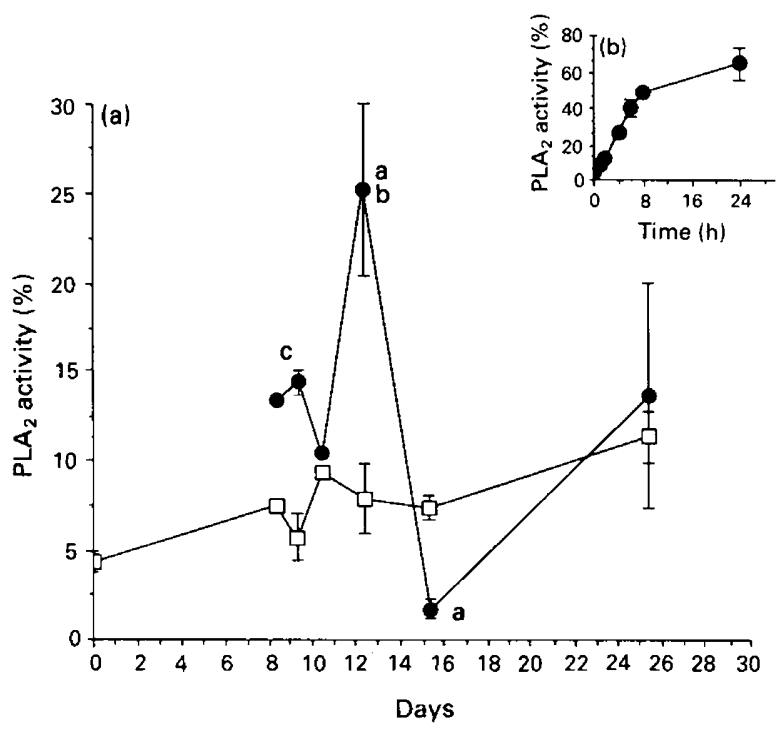

Fig. 4. (a) Activity of phospholipase $A_{2}$ (PLA $)$ in serum ( $\square$ ) and embryo-fetal fluid (EFF, during gestation in rabbits. Each point represents the mean \pm SEM of four samples, except at days 8 and $10(n=1)$. a, Significantly different from the following EFF value $(P<0.05)$; b, significantly different from the autologous serum value $(P<0.01)$; and $\mathrm{c}$, significantly different from the day-12 EFF value $(P<0 \cdot 05)$. (b) Kinetics of PLA $\mathrm{PA}_{2}$ activity in EFF on day 12.

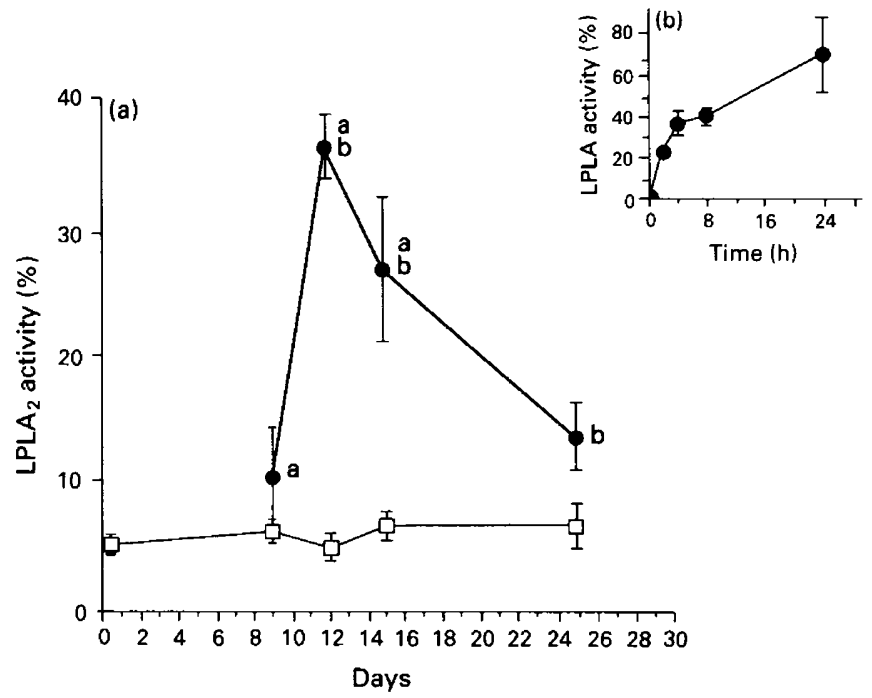

Fig. 5. (a) Activity of lysophospholipase A (LPLA) in sera ( $\square$ ) and embryo-fetal fluid (EFF, -) during gestation in rabbits. Each point represents the mean \pm SEM of six samples. a, Significantly different from the following EFF value $(P<0.05)$; and $\mathrm{b}$, significantly different from the autologous serum value $(P<0.01)$. (b) Kinetics of LPLA activity in EFF on day 12. 
rabbit heated blood serum (RHBS) and to a variable volume of phosphate buffer to obtain $1.5 \mathrm{ml}$ as the final volume. Absorbance at $540 \mathrm{~nm}$ from the supernatant was measured $6 \mathrm{~h}$ after the addition of erythrocytes to the sample.

\section{Statistical tests}

Unless otherwise specified, all statistical tests were done with the Duncan Kramer multiple-range test.

\section{Results}

Phosphatidylcholine is the most prominent phospholipid in EFF and serum (Fig. 1a). TLC revealed that its concentration decreased in EFF from day 9 to day 12 (Figs la and 2). Incubation of $\left[{ }^{14} \mathrm{C}\right](\mathrm{PC})$ in serum or EFF generated labelled fatty acid (Fig. lb) and this activity was higher in EFF on day 12 than in any other sample tested. At days 8 and 9, LPC concentrations in EFF were high, which was concomitant with a high degree of erythrocyte haemolysis (Fig. 3). There was a strong linear correlation $(P<0.001)$ between LPC concentrations and haemolysis; values for both in EFF on day 12 (Table 1) were significantly lower than on day 9 in EFF $(P<0.05)$ or in sera $(P<0.01)$. Similar tendencies were observed with all the samples tested $(n=14$; results not shown). Addition of $\mathrm{PLA}_{2}$ to the sera increased its haemolytic activity significantly, but PLA alone had no effect (Table 2). Phosphatidylcholine was not detectable in EFF on day 6.5 or after day 12 (Table 3); at days 7 and 8 , the concentration in EFF increased to reach maximum values at day 9 (Table 3 ).

The variation in LPC concentrations in EFF was characterized during the pregnancy cycle by studying its metabolism. Considering the low LPLA activity, at day 9, the phospholipids were probably hydrolysed by PLA $_{2}$ to generate lysophospholipids, which in turn were slowly metabolized into fatty acid and glycerylphosphorylcholine-like compounds. This ensures a high concentration of the fusigenic compound. At day $12, \mathrm{PLA}_{2}$ activity was double that at day 9 (Fig. 4), but, since the substrates for this enzyme (phospholipids, phosphatidylcholine) were at their minimal concentration (Fig. 3), the production of lysophospholipids, such as LPC, was very low (Table 1). Even if some lysophospholipids were produced at day 12, they would be immediately hydrolysed via LPLA. The activity of this enzyme is three times higher at day 12 of pregnancy than at day 9 (Fig. 5). Taken as a whole, these results explain the high LPC concentrations observed at days 8 and 9 and the low concentrations in EFF from day 10 to day 25 of pregnancy.

\section{Discussion}

Implantation of rabbit blastocysts involves cell fusion. It starts with the formation of many syncytial trophoblastic knobs in the abembryonic hemisphere of the blastocyst (Schlafke \& Enders, 1975). This first step occurs before implantation has started, i.e. before day 7, when apposition of the blastocyst has already occurred (Segalen \& Chambon, 1983). Within the next few hours, the knobs come in contact with antimesometrial, unmodified, uterine, epithelial cells and adhere to them (Böving, 1962; Steer, 1970, 1971a; Enders \& Schlafke, 1979). The gland openings seem to be the preferential sites of attraction for the trophoblastic knobs, which fuse with uterine epithelial cells (Segalen \& Chambon, 1983). The epithelium then becomes syncytial and fusion becomes general about 8.5 or 9 days post coitum (Böving, 1962). Thus, the whole process of implantation progresses rapidly from apposition to adhesion (Segalen \& Chambon, 1983) and then from adhesion to penetration (Enders \& Schlafke, 1969; Steer, 1971b). Since trophoblastic knobs appear first and since knobs fuse with uterine epithelial cells before fusion of the epithelial cells with each other, we suggest that a wave of fusion events originates from the trophoblastic part of the blastocyst and results in implantation. The advantage of these events to the pregnant animal would be that only localized areas of the embryo and the uterine epithelium would fuse, thus limiting 
invasion by the penetrating embryo. Our observations strongly suggest that LPC, with its fusigenic properties (Shohet \& Haley 1972; Weltzien, 1979), could be responsible for this fusion; the similarity between LPC concentrations and haemolytic activity shown in this study is in agreement with such an interpretation. More precisely, LPC concentrations and haemolysis in EFF increase and reach high values only during days 7 to 9 , which is the time of implantation in rabbits (Larsen, 1961; Böving, 1962); but why PC increases from day 6.5 to days 8 and 9 is unknown.

The results showing an increase in haemolytic properties of blood serum after addition of commercial preparations of PLA $\mathrm{A}_{2}$ further support the role of LPC in cell fusion. Addition of PLA 2 increases transformation of the endogenous phospholipids present in RHBS on day 9 into lysophospholipids, thus increasing the haemolytic power of the serum.

The fusigenic activity of the high LPC concentrations in blood would normally endanger the erythrocytes of the female. However, the high concentrations of proteins and cholesterol found in the sera, compared with the content in EFF, could reduce this effect since (i) cholesterol is known to reduce the fusigenic properties of LPC by replacing the missing fatty acyl chain thus making the LPC more cylindrical than wedge-shaped (Rand et al., 1975) and (ii) serum albumin also reduces the haemolysis (Dingle \& Lucy, 1962). The erythrocytes of the female would therefore not be damaged. Moreover, the presence of glucose and ATP in the serum would help the erythrocytes metabolize the LPC into non-lytic products preventing LPC from accumulating at the lytic level. In blastocoelic fluid, there are no erythrocytes, thus allowing LPC accumulation.

Since arachidonic acid is a by-product of the chemical reaction that produces LPC, we suggest that, as the embryo comes into closer contact with the maternal immune system, it produces prostaglandin $\mathrm{E}_{2}\left(\mathrm{PGE}_{2}\right)$, via arachidonic acid, and therefore suppresses production of interleukin 2 (IL-2) (Nicholas \& Panayi, 1985), which inhibits T-cell transformation (Szekeres-Bartho et al., 1983; Clark, 1985; Szekeres-Bartho et al., 1985a, b) and results in local immunosuppression. This possibility is supported by the data of Lambert et al. (1989). The demonstration that luminal epithelial cells at implantation sites mobilize arachidonic acid from phospholipids (Moulton \& Russell, 1989) is also in agreement with this interpretation. Moreover, it has been shown that PAF perturbs arachidonic acid metabolism (Shaw et al., 1981) and increases its catabolism by the cyclooxygenase pathway leading to the synthesis of $\mathrm{PGE}_{2}$ (Schlondorff et al., 1984; Billah et al., 1985). It also increases the synthesis of $\mathrm{PGE}_{2}$ from an enriched glandular fraction of human endometrium without altering the synthesis of $\mathrm{PGF}_{2 \alpha}$ (Smith \& Kelly, 1988). Uterine PAF increases in pregnant rabbits to reach a maximum concentration on day 5 and then returns to the oestrous concentration by day 7 of pregnancy. The decline was greatest at the implantation sites, suggesting that the blastocyst could be the causal factor (Angle et al., 1988). The increasing PLA 2 activity observed in blastocyst/yolk sac fluid from the time of implantation up to day 12 (Fig. 4) may be this 'causal factor'. Indeed, PLA 2 acts upon PAF to produce lyso-PAF (Harper, 1989), which has no biological activity (Acker et al., 1989). However, lyso-PAF can compete with PAF-binding sites in the endometrium and therefore it can downregulate the expression of these sites once implantation has been initiated (Harper, 1989). As lyso-PAF comigrates with LPC, in our TLC system, further studies will be directed at evaluating concentrations of PAF and lyso-PAF in blastocoelic fluid in relation to their possible role in the fusion accompanying implantation as well as in the immunosuppressive condition that prevails during implantation.

It has been proposed that epithelial cell fusion also occurs in the uterus of pseudopregnant rabbits (Davies \& Hoffman, 1975). Indeed, from day 4 to day 6 the cells showed (i) a characteristic protrusion of the cytoplasm into the uterine lumen in the form of a dome-like prominence, (ii) that portions of the nucleus were frequently entrapped within the protuberances and (iii) morecondensed nuclei with indentation of the nuclear membrane and condensation of the chromatin. As suggested by Davies \& Hoffman (1975), these modifications seemed to be a prelude to the succeeding phase of fusion (days 6-13 of pseudopregnancy). However, all these morphological alterations of the cells are characteristics of apoptosis (Wyllie et al., 1980; Walker et al., 1988). Such a phenomenon has been demonstrated in the epithelium of the female genital tract of several species 
(Hopwood \& Levison, 1976; Sandow et al., 1979; Verhage et al., 1984). This was particularly evident in rabbit uterine epithelium from day 6 to day 9 of pseudopregnancy (Nawaz et al., 1987).

We suggest that lysophospholipids are involved in the formation of the syncytiotrophoblast and in the fusion of uterine epithelial cells during blastocyst implantation in rabbits.

We are grateful to L. Blouin for excellent technical assistance. This work was supported by an NSERC grant.

\section{References}

Acker, G., Hecquet, F., Etienne, A., Braquet, P. \& Mencia-Huerta, J.M. (1988) Role of platelet-activating factor (PAF) in the ovoimplantation in the rat: effect of the specific PAF-acether antagonist, BN 52021. Prostaglandins 35, 233-241.

Acker, G., Braquet, P. \& Mencia-Huerta, J.M. (1989) Role of platelet-activating factor (PAF) in the initiation of the decidual reaction in the rat. Journal of Reproduction and Fertility 85, 623-629.

Ahkong, Q.F., Fisher, D., Tampion, W. \& Lucy, J.A. (1973) The fusion of erythrocytes by fatty acids, esters, retinol and $\alpha$-tocopherol. Biochemical Journal 136, 147-155.

Angle, M.J., Jones, M.A., Mcmanus, L.M., Pinckard, R.N. \& Harper, M.J.K. (1988) Platelet-activating factor in the rabbit uterus during early pregnancy. Journal of Reproduction and Fertility 83, 711-722.

Billah, M.M., Di Renzo, G.C., Ban, C., Truong, C.R., Hoffman, D.R., Anceschi, M.M., Bleasdale, J.E. \& Johnson, J.M. (1985) Platelet-activating factor metabolism in human amnion and the responses of this tissue to extracellular platelet-activating factor. Prostaglandins 30, 841-850.

Böving, B.G. (1962) Anatomical analysis of rabbit trophoblast invasion. Contribution to Embryology 254, 33-55.

Clark, D.A. (1985) Prostaglandins and immunoregulation during pregnancy. American Journal of Reproductive Immunology and Microbiology 9, $111-112$.

Davies, J. \& Hoffman, L.H. (1975) Studies on the progestational endometrium of the rabbit. II. Electron microscopy, day 0 to day 13 of gonadotrophininduced pseudopregnancy. American Journal of Anatomy 142, 335-366.

Dey, S.K. \& Johnson, D.C. (1986) Embryonic signals in pregnancy. Annals of the New York Academy of Sciences 471, 49-62.

Dingle, J.T. \& Lucy, J.A. (1962) Studies on the mode of action of excess of vitamin A. 5. The effect of vitamin $A$ on the stability of the erythrocyte membrane. Biochemical Journal 84, 611-621.

Edwards, R.G. (1980) Conception in the Human Female. Academic Press, London.

Enders, A.C. \& Schlafke, S. (1969) Cytological aspects of trophoblast-uterine interaction in early implantation. American Journal of Anatomy 125, 1-30.

Enders, A.C. \& Schlafke, S. (1971) Penetration of the uterine epithelium during implantation in the rabbit. American Journal of Anatomy 132, 219-240.

Enders, A.C. \& Schlafke, S. (1979) Comparative aspects of blastocyst-endometrial interactions at implantation. In Maternal Recognition of Pregnancy, pp. 3-32. Ciba Foundation symposium 64, Elsevier/ North-Holland, Amsterdam.

Finn, A.C. (1967) The implantation reaction. In Biology of the Uterus, pp. 245-295. Ed. R. M. Wynn, Plenum Press, NY.

Harper, M.J.K. (1989) Platelet-activating factor: a paracrine factor in preimplantation stages of reproduction? Biology of Reproduction 40, 907-913.

Hopwood, D. \& Levison, D.A. (1976) Atrophy and apoptosis in the cyclical human endometrium. Journal of Pathology 119, 159-166.

Kennedy, T.G. (1985) Evidence for the involvement of prostaglandins throughout the decidual cell reaction in the rat. Biology of Reproduction 33, 140-146.

Kennedy, T.G. (1986) Prostaglandins and uterine sensitization for the decidual cell reaction. Annals of the New York Academy of Sciences 476, 43-48.

Kennedy, T.G. (1987) Interactions of eicosanoids and other factors in blastocyst implantation. In Eicosanoids and Reproduction, pp. 123-138. Ed. M. D. Mitchell. CRC Press, Boca Raton.

Lambert, R.D., Roy, R., Morin, C., Beaudoin, J., Langlais, J. \& Pandian, A.M.C. (1989) Modulation of the immunosuppressive activities by blastocoelic fluid during rabbit pregnancy. Journal of Reproductive Immunology 15, 257-268.

Larsen, J.F. (1961) Electron microscopy of the implantation site in the rabbit. American Journal of Anatomy 109, 319-334.

Moulton, B.C. \& Koenig, B.B. (1988b) Biochemical responses of the luminal epithelium and uterine sensitization. Annals of the New York Academy of Sciences 476, 95-109.

Moulton, B.C. \& Russell, P.R. (1989) Arachidonic acid in uterine phospholipid during early pregnancy and following hormone treatment. Biology of Reproduction 41, 821-826.

Nawaz, S., Lynch, M.P., Galand, P. \& Gerschenson, L.E. (1987) Hormonal regulation of cell death in rabbit uterine epithelium. American Journal of Pathology $127,51-59$.

Nicholas, N.S. \& Panayi, G.S. (1985) Inhibition of interleukin-2 production by retroplacental sera: a possible mechanism for human fetal allograft survival. American Journal of Reproductive Immunology and Microbiology 9, 6-11.

Psychoyos, A. (1986) Uterine receptivity for nidation. Annals of the New York Academy of Sciences 476, 36- 42 .

Rand, R.P., Pangborn, W.A., Purdon, A.D. \& Tinker, D.O. (1975) Lysolecithin and cholesterol interact stoichiometrically forming bimolecular lamellar structures in the presence of excess water, or lyso- 
lecithin or cholesterol. Canadian Journal of Biochemistry 53, 189-195.

Sandow, B.A., West, N.B., Norman, R.L. \& Brenner, R.M. (1979) Hormonal control of apoptosis in hamster uterine luminal epithelium. American Journal of Anatomy 156, 15-36.

Schlafke, S. \& Enders, A.C. (1975) Cellular basis of interaction between trophoblast and uterus at implantation. Biology of Reproduction 12, 41-65.

Schlondorff, D., Satriano, J.A., Hagege, J., Perez, J. \& Baud, L. (1984) Effect of platelet-activating factor and serum-treated zymosan on prostaglandin $E_{2}$ synthesis, arachidonic acid release, and contraction of cultured rat mesangial cells. Journal of Clinical Investigation 73, 1227-1231.

Segalen, J. \& Chambon, Y. (1983) Ultrastructual aspects of the antimesometrial implantation in the rabbit. Acta Anatomica 115, 1-7.

Shaw, J.O., Klusick, S.J. \& Hanahan, D.J. (1981) Activation of rabbit platelet phospholipase and thromboxane synthesis by 1-0-hexadecyl/octadecyl2-acetyl-sn-glyceryl-3-phosphorylcholine (platelet activating factor). Biochimica et Biophysica Acta 663, 222-229.

Shelesnyak, M.C. (1986) A history of research on nidation. Annals of the New York Academy of Sciences 476, 5-24.

Shelesnyak, M.C. \& Marcus, G.J. (1970) Steroidal conditioning of the endometrium for nidation. Advances in the Biosciences 6, 303-316.

Shohet, S.B. \& Haley, J.E. (1972) Red cell membrane shape and stability: relation to cell lipid renewal pathways and cell ATP. Nouvelle Revue Française d'Hématologie 12, 761-770.

Smith, S.K. \& Kelly, R.W. (1988) Effect of plateletactivating factor on the release of PGF- $2 \alpha$ and PGE2 by separated cells of human endometrium. Journal of Reproduction and Fertility 82, 271-276.

Steer, H.W. (1970) The trophoblastic knob of the preimplanted rabbit blastocyst: a light and electron microscopic study. Journal of Anatomy 107, 315-325.
Steer, H.W. (1971a) Implantation of the rabbit blastocyst: the adhesive phase of implantation. Journal of Anatomy 109, 215-227.

Steer, H.W. (1971b) Implantation of the rabbit blastocyst: the invasive phase. Journal of Anatomy 110, 445-462.

Szekeres-Bartho, J., Csernus, C. \& Pacsa, A.S. (1983) Progesterone-prostaglandin balance influences lymphocyte function in relation to pregnancy. American Journal of Reproductive Immunology and Microbiology 4, 139-141.

Szekeres-Bartho, J., Falkay, G., Torok, A. \& Pacsa, A.S. (1985a) The mechanism of the inhibitory effect of progesterone on lymphocyte cytotoxicity. I. Progesterone treated lymphocytes release a substance inhibiting cytotoxicity and prostaglandin synthesis. American Journal of Reproductive Immunology and Microbiology 9, 15-18.

Szekeres-Bartho, J., Falkay, G., Torok, A. \& Pacsa, A.S. (1985b) The mechanism of the inhibitory effect of progesterone on lymphocyte cytotoxicity. II. Relationship between cytotoxicity and the cyclooxygenase pathway of arachidonic acid metabolism. American Journal of Reproductive Immunology and Microbiology 9, 19-22.

Verhage, H.G., Murray, M.K., Boomsma, R.A., Rehfeldt, P.A. \& Jaffe, R.C. (1984) The post ovulatory cat oviduct and uterus: correlation of morphological features with progesterone receptor levels. Anatomical Record 208, 521-531.

Walker, N.I., Harmon, B.V., Gobé, G.C. \& Kerr, J.F.R. (1988) Patterns of cell death. Methods and Achievements in Experimental Pathology 13, 18-54.

Weltzien, H.V.(1979) Cytolytic and membrane perturbing properties of lysophosphatidylcholine. Biochimica et Biophysica Acta 559, 259-287.

Wyllie, A.H., Kerr, J.F.R. \& Currie, A.R. (1980) Cell death: the significance of apoptosis. International Review of Cytology 68, 251-306.

Received 3 December 1991 